\title{
The Effect of Diaphragm Therapy on Comfort in COPD Patients in The Cempaka Pavilion, Jombang Hospital
}

\author{
Agustina Maunaturrohmah $^{1 \text { (corresponding author) }}$, Endang Yuswatiningsih ${ }^{2}$ \\ ${ }^{1}$ Department of Nursing, STIKes ICME Jombang, Indonesia \\ ${ }^{2}$ Department of Nursing, STIKes ICME Jombang, Indonesia
}

Submitted: November 22, 2018 -Revised: April 13, 2019 -Accepted: May 8, 2019 -Published: May 31, 2019

\begin{abstract}
Patients who experience shortness of breath will cause discomfort in body function and limited independence, so patients tend to avoid daily physical activities that cause immobilization, the relationship of patients with the social environment decreases. The aim of this study was to analyze the effect of diaphragm therapy on the comfort of patients with chronic obstructive pulmonary disease (COPD). The design of this study was one group pre-post test. The population were all patients in the Cempaka pavilion at Jombang Hospital with an average of 26 patients per month. The sample size were 20 respondents, selected using simple random sampling technique. Data were collected using questionnaire, then analyzed using Paired Sample T Test. The results showed that before being given diaphragm therapy, 13 respondents $(65 \%)$ felt uncomfortable and after giving diaphragm therapy, 14 respondents $(70 \%)$ felt comfortable. Statistical test results with Paired Sample T Test obtained pvalue of 0.035 . Conclusion: there is an effect of diaphragm therapy on comfort in patients with COPD.
\end{abstract}

Keywords: diaphragm therapy; comfort; COPD

\section{INTRODUCTION}

Chronic Obstruction Pulmonary Disease is a type of non-communicable disease group, is still a health problem in the world. Chronic obstructive pulmonary disease is not only a problem in developed countries, but also a problem in developing countries like Indonesia. This problem is characterized by the higher active smokers in Indonesia. Clinical symptoms include increased breathing effort, coughing, sputum production, and limited activity. Complaints of patients experiencing shortness of breath will cause discomfort in body function and limitedness of independence, so that patients tend to avoid daily physical activity, cause immobilization, the relationship of patients with the social environment decreases. ${ }^{(2)}$

WHO data in 2010 states that Indonesia is the 3rd smoking country after China and India. The world number in 2012 shows that chronic obstructive pulmonary disease in 210 people, the fifth cause of death in 2012 is expected to increase to 4 by 2030. ${ }^{(3)}$ Acoording to Khaled (2012), the prevalence of chronic obstructive pulmonary disease in Southeast Asian countries is estimated at $6.3 \%$ with the highest prevalence in Vietnam $(6.7 \%)$ while in Indonesia it is estimated that there are around 4.8 million sufferers of chronic obstructive pulmonary disease. The data on the prevalence of chronic obstructive diseases in Indonesia reached 5.6 million patients with an East Java pervalence of 3.6\%. ${ }^{(4)}$ Data in Jombang District Hospital Jombang Pavilion room for patients who were hospitalized with chronic obstruction in 2015 totaled 327 people, in 2016 reached 373 people, while in 2017 from January - February reached 55 people. $^{(5)}$

High smoking habits, air pollution and biomass causes risk factors for chronic obstructive pulmonary disease. Chronic obstructive pulmonary disease is a systemic disease that has a relationship between metabolic involvement, skeletal muscle and genetic molecular. Skeletal muscle dysfunction is the main thing that plays a role in the limited activity of patients with systemic inflammation, an increased risk of cardiovascular disease, osteoporosis, and depression are systemic manifestations of chronic obstructive pulmonary disease. ${ }^{(7)}$ This will have a negative impact on the patient's physiological, sociological, and environmental conditions of the patient's comfort. Comfort is a pattern of pleasure, relief and perfection in the physical, psychospiritual, environmental and social dimensions. ${ }^{(8)}$ Comfort is the main goal of nursing because with the comfort of recovery patients can be obtained. ${ }^{(9)}$

Breathing exercises can be used as a reference for non-pharmacological actions. The breathing technique used is diaphragmatic breathing. Respiratory training is done by relaxing the upper chest, arms and shoulders. ${ }^{(10)}$ Breathing exercises in patients with chronic obstructive pulmonary disease are intended to improve the function of the breathing apparatus, with the aim of being able to train patients to regulate breathing. The advantages of diaphragmatic breathing exercises are that it optimizes the use of diaphragmatic muscles and strengthens the diaphragm during breathing (Muttaqin, 2008). Using a technique consisting of 2-4-2 namely: two seconds with 
inhalation, followed by four seconds holding your breath by allowing the abdominal muscles to bulge as much as possible, and two seconds of inhalation or exhale with frequency 3 times a week. ${ }^{(11)}$

The aim of this study was to determine the effect of diaphragm therapy on comfort in patients with COPD.

\section{METHODS}

The type of this study was pre-experimental research, a research design that is used to find a causal relationship with the existence of research involvement in manipulating the independent variables. ${ }^{(12)}$ The research design used was one group pre test post test design which was an experimental design by pre-test before giving intervention then after being given an intervention post test. ${ }^{(13)}$

The population was all patients of chronic obstructive pulmonary disease in the Cempaka Room of Jombang District Hospital in the last 3 months from December to February with an average of 26 people / month. The sample in this study were some patients with chronic obstructive pulmonary disease in the Cempaka Pavillion Room in Jombang District Hospital, totaling 20 people, selected using simple random sampling technique.

Data collection for comfort levels was measured by the General comfort questionnaire questionnaire, with 48 items using a Likert scale 1, 2, 3, 4, with the highest score indicating high comfort, taken 24 items from 2 parameters, namely physical comfort and psychospiritual nature which are positive statements and negative statements. Descriptive analysis using T-score while bivariate analysis, followed by Paired Sample T-Test.

\section{RESULTS}

\section{Characteristics of Respondents Based on Age}

Table 1. Distribution of respondents based on age in the pavilion room of Jombang District Hospital in 2018

\begin{tabular}{|c|c|c|c|}
\hline No & Age & Frequency & Percentage \\
\hline 1 & 20-30 years & 1 & 5 \\
2 & 31-40 years & 2 & 10 \\
3 & 41-50 years & 6 & 30 \\
4 & 51-60 years & 11 & 55 \\
\hline & Total & 20 & 100 \\
\hline
\end{tabular}

Table 1 shows that out of 20 respondents, the majority of respondents were 51-60 years old with 11 people $(55 \%)$.

\section{Characteristics of Respondents Based on Employment}

Table 2. Distribution of respondents based on employment in the Cempaka pavilion room in Jombang District Hospital in 2018

\begin{tabular}{|c|c|c|c|}
\hline No & Employment & Frequency & Percentage \\
\hline 1 & Employee & 9 & 45 \\
2 & Unemployment & 11 & 55 \\
\hline & Total & 20 & 100 \\
\hline
\end{tabular}

Table 2 shows that most of the 20 respondents did not work with 11 respondents $(55 \%)$.

\section{Characteristics of Respondents Based on Information about Diaphragmatic Breathing}

Table 3. Distribution of respondents based on information about diaphragmatic breathing in the Cempaka pavilion room in Jombang District Hospital in 2018

\begin{tabular}{|c|c|c|c|}
\hline No & Information & Frequency & Percentage \\
\hline 1 & Ever & 5 & 25 \\
2 & Never & 15 & 75 \\
\hline & Total & 20 & 100 \\
\hline
\end{tabular}


Table 3 shows that of the 20 respondents, almost all of them never knew information about diaphragmatic breathing exercises with a total of 15 respondents $(78.3 \%)$.

\section{Characteristics of Respondents Based on Smoking}

Table 4. Frequency distribution of respondents based on smoking in the Cempaka pavilion room in Jombang District Hospital in 2018

\begin{tabular}{|c|c|c|c|}
\hline No & Smoke & Frequency & Percentage \\
\hline 1 & Yes & 12 & 60 \\
2 & No & 8 & 40 \\
\hline & Total & 20 & 100 \\
\hline
\end{tabular}

Table 4 shows that of the 20 respondents, the majority of those who smoked were 12 respondents $(60 \%)$.

\section{Characteristics of Respondents Based on the Number of Cigarettes / Day}

Table 5. Distribution of respondents based on the number of cigarettes/day in the Cempaka pavilion room in Jombang District Hospital in 2018

\begin{tabular}{|c|c|c|c|}
\hline No & Number of cigarettes / day & Frequency & Percentage \\
\hline 1 & $<3$ & 1 & 6.7 \\
2 & $>4$ & 11 & 93.3 \\
\hline & Total & 12 & 100.0 \\
\hline
\end{tabular}

Table 5 shows that most of the 15 respondents were almost entirely the number of cigarettes in a day $\geq 4$ with a total of 14 respondents $(93.3 \%)$.

\section{Comfort of Chronic Obstructive Pulmonary Patients before Diaphragmatic Breathing}

Table 6. Distribution of respondents based on the comfort of patients with chronic obstructive pulmonary disease before diaphragmatic breathing in the Cempaka pavilion room in Jombang District Hospital in 2018

\begin{tabular}{|c|c|c|c|}
\hline No & Pre test & Frequency & Percentage \\
\hline 1 & Uncomfortable & 13 & 65 \\
2 & Comfortable & 7 & 35 \\
\hline & Total & 23 & 100 \\
\hline
\end{tabular}

Table 6 shows that of the 20 respondents most of the respondents experienced discomfort before diaphragmatic breathing was done with the number of 13 respondents $(56.5 \%)$.

\section{Comfort of Patients with Chronic Obstructive Pulmonary Disease after Diaphragmatic Breathing}

Table 7. Distribution of respondents based on the comfort of patients with chronic obstructive pulmonary disease after diaphragmatic breathing at the Cempaka pavilion in Jombang District Hospital in 2018

\begin{tabular}{|c|c|c|c|}
\hline No & Post-test & Frequency & Percentage \\
\hline 1 & Uncomfortable & 6 & 30 \\
2 & Comfortable & 14 & 70 \\
\hline & Total & 23 & 100 \\
\hline
\end{tabular}

Table 7 shows that of the 20 respondents most experienced comfort after diaphragmatic breathing was 14 respondents $(70 \%)$. 
The Results of the Measurement of Comfort of Patients with Chronic Obstructive Pulmonary Disease before and after Treatment

Table 8. Results of comfort measurement of patients with chronic obstructive pulmonary disease before and after treatment at the Cempaka pavilion in Jombang District Hospital in 2018

\begin{tabular}{|c|c|c|c|c|}
\hline Comfort of COPD patients & Pre test & Percentage & Post-test & Percentage \\
\hline Uncomfortable & 13 & 65 & 6 & 30 \\
Comfortable & 7 & 35 & 14 & 70 \\
\hline Total & 20 & 100 & 20 & 100 \\
\hline \multicolumn{4}{|c}{ Paired sample t test nilai $\mathrm{p}=0.035$} \\
\hline
\end{tabular}

Table 8 shows that out of 20 respondents with chronic obstructive pulmonary disease most of the respondents experienced discomfort before being given diaphragmatic breathing by 13 respondents (65\%), whereas after being given diaphragmatic breathing most respondents experienced comfort in the number of 14 respondents or $(70 \%)$.

The p-value of paired sample t test was 0.035 (there is an effect of diaphragm therapy on comfort in patients with COPD).

\section{DISCUSSION}

\section{Comfort of Patients with Chronic Obstructive Pulmonary Disease before Diaphragmatic Breathing}

The results of the study explained that most of the patients with chronic obstructive pulmonary disease felt uncomfortable before diaphragmatic breathing was done by the number of 13 respondents (65\%). An individual's comfort aspect consists of 4 aspects, namely physical comfort, psychospiritual, environmental, and social, cultural. The reality as a condition has fulfilled basic human needs that are individual and holistic. The fulfillment of comfort can cause a sense of well-being for individuals. ${ }^{(14)}$ The theory of NANDA International 2018-2020 also explains that comfort is a pattern of pleasure, relief, and perfection in the physical, psychospiritual, environmental, and social dimensions. ${ }^{(8)}$

Researchers argue that before diaphragmatic breathing the patient feels uncomfortable, with an average of 73.3 who feel uncomfortable. Data from the study stated that the average patient feels uncomfortable in physical comfort, this is because most respondents answered "I cannot overcome my pain" with an average number of 3.1. Other clinical symptoms include patients who look like: increasing breathing effort, coughing, the general condition of the patient looks pale, the patient looks anxious and confused. Complaints from patients with chronic obstructive pulmonary disease can cause the patient to feel uncomfortable, which will cause the patient to experience comfort problems in physical comfort.

Physical comfort that is a comfort disorder related to body sensation. Visible physical needs such as pain, pain, nausea, vomiting, shivering. ${ }^{(14)}$ Patients feel discomfort in body function, and experience the limitations of independence, so patients tend to avoid daily physical activities, causing immobilization, the relationship of patients with the social environment decreases. ${ }^{(2)}$

The research data also found that of the 13 respondents who felt uncomfortable, in question 24 the respondent felt impatient with the current illness, with a total of 3.8. Researchers believe that COPD patients will experience anxiety because of the actions taken during treatment and the limitations in carrying out daily activities. Patients sometimes with a high voice when answering questions, patients also often complain of symptoms of increased stomach acid so that with some problems that arise the patient feels impatient in dealing with the problem now. Asmadi ${ }^{(15)}$ explained that the characteristics of a person with mild anxiety is with occasional shortness of breath, a slight pulse and pressure, mild symptoms of the stomach, slightly wrinkled face, trembling of the lips, fine tremor of the hand, and rising voices. According to Herlina ${ }^{(16)}$ psychospiritual comfort includes self-confidence and motivation so that patients are more calm when undergoing painful invasive procedures. A person is said to have psychospiritual comfort when freed from impurity, fear and stress. ${ }^{(14)}$

Data from the research results in the Cempaka pavilion in Jombang District Hospital stated that most of the respondents were 51-60 years old with 11 people (55\%). According to researchers the comfort disorder of patients with chronic obstructive pulmonary disease is mostly suffered by patients who are elderly, namely age from 51-60 years, because when age starts dusk, the elderly begin to decline. Decrease in physical ability is 
characterized by the patient looking anxious, easily tired, thus disrupting daily activities. Age is one of the variables that influence the perception of total comfort. Age will affect normal physical characteristics. ${ }^{(14)}$ The ability to participate in a preopertif physical examination is also influenced by age. ${ }^{(15)}$

\section{Comfort of Patients with Chronic Obstructive Pulmonary Disease after Diaphragmatic Breathing}

Almost all of the patients with chronic obstructive pulmonary disease stated that they were comfortable after diaphragmatic breathing was done with a number of 14 respondents (70\%). Data from research conducted in the Cempaka pavilion in Jombang District Hospital stated that out of 14 respondents who felt comfortable in physical comfort after diaphragmatic breathing was number 3, respondents said they felt strong enough to walk.

Researchers argue that with diaphragmatic breathing, the diaphragm muscle will function optimally so that the respondent is able to regulate breathing and the situation of the respondent will become more relaxed. This situation can make respondents feel comfortable. Muttaqin ${ }^{(17)}$ describes the purpose of diaphragmatic breathing is to optimize the use of diaphragmatic muscles and strengthen the diaphragm during breathing.

Diaphragmatic breathing exercises are carried out with the aim that patients with ventilation problems can achieve more optimal ventilation, be contaminated, efficient, and can reduce respiratory work. Breathing exercises are carried out by relaxing the upper chest, arms and shoulders. Breathing exercises in patients with chronic obstructive pulmonary disease are intended to improve the function of the breathing apparatus, with the aim of being able to train patients to regulate breathing.

\section{Effect of Diaphragmatic Breathing on the Comfort of Patients with Chronic Obstructive Pulmonary Disease}

Data from the study of diaphragmatic breathing therapy at the Cempaka pavilion in Jombang District Hospital showed that most of the 20 respondents with chronic obstructive pulmonary disease felt uncomfortable before being given diaphragmatic respiration. comfortable to be 6 respondents (30\%). Diaphragmatic breathing affects the comfort level of patients with chronic obstructive pulmonary disease, this is evidenced by the change in patients who before being given respiratory diaphragm experience comfort problems become comfortable after being given diaphragmatic respiratory treatment. Diaphragmatic breathing exercises that are given to respondents are easy exercises, done in a slow, conscious, and non-compelling way. Diaphragmatic breathing exercises are carried out routinely for 3 days causing respondents to experience physical and mental changes. With the diaphragmatic breathing the respondent's muscles will become stretched and relaxed so that the patient makes the mind calm down the patient can feel physically comfortable and can reduce the tightness that the patient complains.

Breathing exercises can be used as a reference for non-pharmacological actions. The breathing technique used is diaphragmatic breathing. Breathing exercises are performed by relaxing the upper chest, arms and shoulders ${ }^{(10)}$. Breathing exercises in patients with chronic obstructive pulmonary disease are intended to improve the function of the breathing apparatus, with the aim of being able to train patients to regulate breathing. The advantages of diaphragmatic breathing exercises are the optimal use of diaphragmatic muscles and strengthening of the diaphragm during breathing. ${ }^{(17)}$

\section{CONCLUSION}

The conclusion of this study was that there is an effect of diaphragm therapy on comfort in patients with chronic obstructive pulmonary disease (COPD)

\section{REFERENCES}

1. Depkes RI. Control Guidelines for Obstructive Pulmonary Disease (Pedoman Pengendalian Penyakit Paru Obstruktif). Jakarta: Depkes RI; 2008.

2. Khotimah S. Endurance Training Improves Quality of Life Better than Respiratory Exercise in COPD Patients in BP4 Yogyakarta (Latihan Endurance Meningkatkan Kualitas Hidup Lebih Baik daripada Latihan Pernafasan pada Pasien PPOK di BP4 Yogyakarta). Sport and Fitness Journal. 2013:1:20-32.

3. WHO. Chronic Obstructive Pulmonary Disease. Geneva: WHO; 2010.

4. Kemenkes RI. Basic Health Research 2013: Interview Guidelines for Data Collection Officers (Riset Kesehatan Dasar 2013: Pedoman Pewawancara Petugas Pengumpul Data). Jakarta: Badan Litbangkes Kemenkes RI: 2013. 
5. RSUD Jombang. Data on Chronic Obstruction Pulmonary Disease Patients in Jombang Regional Hospital (Data Pasien Penyakit Paru Obstruksi Kronik di RSUD Jombang). Jombang: RSUD Jombang; 2017.

6. Sugiarti, Sondari. Overview of Chronic Obstructive Pulmonary Disease in the Mining Area, Muara Enim Regency, South Sumatra (Gambaran Penyakit Paru Obstruktif Kronik di Daerah Pertambangan, Kabupaten Muara Enim, Sumatra Selatan). 2015.

7. Omiati R. Kajian Epidemologis Penyakit Paru Obstruktif Kronik. Jurnal Media Litbangkes. 2013;23(2):8288

8. NANDA. Nursing Diagnosis 2015-2017 (Diagnosis Keperawatan 2015-2017). Jakarta: EGC; 2017.

9. Alligood Mr, Tomey AM. Nursing Theories and Their Work. Louist, Missori: Mosby Elsevier; 2006.

10. Nurun S, Purba A, Defi I. The Effectiveness of Incentive Spirometry Exercise with Diaphragmatic Respiratory Exercise on Lung Function, Functional Capacity and Quality of Life of People with Asthma Bronchial Allergies (Efektifitas Latihan Incentive Spirometry dengan Latihan Pernafasan Diafragma terhadap Fungsi Paru, Kapasitas Fungsional dan Kualitas Hidup Penderita Asma Bronchial Alergi). 2014;46(1).

11. Nugroho S. Respiratory Therapy in Asthma Sufferers (Terapi Pernafasaan pada Penderita Asma). UNY. 2011.

12. Nursalam. Nursing Science Research Methods: A Practical Approach (Metode Penelitian Ilmu Keperawatan: Pendekatan Praktis). Jakarta: Salemba Medika; 2013.

13. Hidayat AAA. Midwifery Research Methods and Data Analysis Techniques (Metode Penelitian Kebidanan dan Teknik Analisa Data). Jakarta: Salemba Medika; 2014.

14. Colcaba K. General Comfort Questionnare [Internet]. 2003 [cited 2018 Aug 9]. Available from http://www.the_comfort_line.com

15. Asmadi. Basic Concepts of Nursing (Konsep Dasar Keperawatan). Jakarta: EGC; 2008.

16. Herlina. Application of Comfort Theory in Child Nursing (Aplikasi Teori Kenyamanan pada Asuhan Keperawatan Anak). Jakarta: FIKES-UPN; 2012.

17. Muttaqin A. Nursing Care Books for Clients with Respiratory System Disorders (Buku ajar Asuhan Keperawatan Klien dengan Gangguan Sistem Pernafasaan). Jakarta: Salemba Medika; 2008. 